\title{
The Acidity of Uracil and Uracil Analogs in the Gas Phase: Four Surprisingly Acidic Sites and Biological Implications
}

\author{
Mary Ann Kurinovich and Jeehiun K. Lee \\ Department of Chemistry, Rutgers University, The State University of New Jersey, Piscataway, New Jersey, USA
}

\begin{abstract}
The gas phase acidities of a series of uracil derivatives (1-methyluracil, 3-methyluracil, 6-methyluracil, 5,6-dimethyluracil, and 1,3-dimethyluracil) have been bracketed to provide an understanding of the intrinsic reactivity of uracil. The experiments indicate that in the gas phase, uracil has four sites more acidic than water. Among the uracil analogs, the N1-H sites have $\Delta \mathrm{H}_{\text {acid }}$ values of 331-333 $\mathrm{kcal} \mathrm{mol}^{-1}$; the acidity of the N3 sites fall between 347-352 kcal $\mathrm{mol}^{-1}$. The vinylic C6 in 1-methyluracil and 3-methyluracil brackets to $363 \mathrm{kcal} \mathrm{mol}^{-1}$, and 369 $\mathrm{kcal} \mathrm{mol}^{-1}$ in 1,3-dimethyluracil; the C5 of 1,3-dimethyluracil brackets to $384 \mathrm{kcal} \mathrm{mol}^{-1}$. Calculations conducted at B3LYP/6-31+ $\mathrm{G}^{*}$ are in agreement with the experimental values. The bracketing of several of these sites involved utilization of an FTMS protocol to measure the less acidic site in a molecule that has more than one acidic site, establishing the generality of this method. In molecules with multiple acidic sites, only the two most acidic sites were bracketable, which is attributable to a kinetic effect. The measured acidities are in direct contrast to in solution, where the two most acidic sites of uracil (N1 and N3) are indifferentiable. The vinylic $\mathrm{C} 6$ site is also particularly acidic, compared to acrolein and pyridine. The biological implications of these results, particularly with respect to enzymes for which uracil is a substrate, are discussed. (J Am Soc Mass Spectrom 2002, 13, 985-995) (c) 2002 American Society for Mass Spectrometry
\end{abstract}

A ccurate measurements of the acidities and basicities of nucleic bases and nucleic base derivatives is essential for understanding issues of fundamental importance in biological systems. Hydrogen bonding modulates recognition of DNA and RNA bases, and the interaction energy between two bonded complementary nucleobases is dependent on the intrinsic basicity of the acceptor atoms as well as on the acidity of donor $\mathrm{NH}$ groups [1, 2]. In addition, understanding the intrinsic reactivity of nucleic bases can shed light on key biosynthetic mechanisms in which nucleobases are substrates [3-8].

The gas phase is a valuable environment in which to examine the properties and reactivity of biological molecules. Biological media, from intracellular environs to the interior of proteins, are seldom aqueous in nature. For example, it has been shown that the interior of proteins is often nonpolar, causing shifts in acidity and basicity and changes in reactivity compared to behavior in aqueous solution [9-11]. The gas phase is the "ultimate" nonpolar environment and therefore allows one to establish intrinsic reactivity in the absence of solvent, and extrapolate the effects of media. Estab-

Published online June 27, 2002

Address reprint requests to Dr. J. K. Lee, Department of Chemistry, Rutgers University, 610 Taylor Road, Piscataway, NJ 08854, USA. E-mail: jklee@rutchem.rutgers.edu lishing thermochemical properties of the nucleobases is of interest for purely chemical reasons, but is also valuable for biological reasons, providing a basis for understanding the role of media on reactivity [9, 12-14]. In essence, gas phase experiments can provide the link between calculations and condensed phase data.

Recently, our studies of nucleobases have focused on the pyrimidine base uracil. While the proton affinities of the most basic sites of the major nucleobases, deoxyribonucleosides, and deoxyribonucleotides have been bracketed, gas phase acidities of the nucleobases are largely unknown [15-18]. Our studies have also been motivated by our interest in two pyrimidine-related enzymes, uracil-DNA glycosylase (UDGase) and orotidine 5'-monophosphate decarboxylase (ODCase). UDGase catalyzes a genome-protecting reaction that cleaves misincorporated uracil from DNA, through an unknown mechanism that presumably involves some form of N1-deprotonated uracil as a leaving group (Scheme 1) [4, 5, 19-23]. ODCase lies along the pyrimidine de novo synthetic pathway, and catalyzes the decarboxylation of orotate ribose-5'-monophosphate to ultimately form uracil ribose-5'-monophosphate (Scheme 2), via a mechanism that presumably involves some form of C6-deprotonated uracil [6, 24-27]. Both mechanisms are hotly debated, the central question being how the uracil anion-whether the $\mathrm{N}^{-}$in 


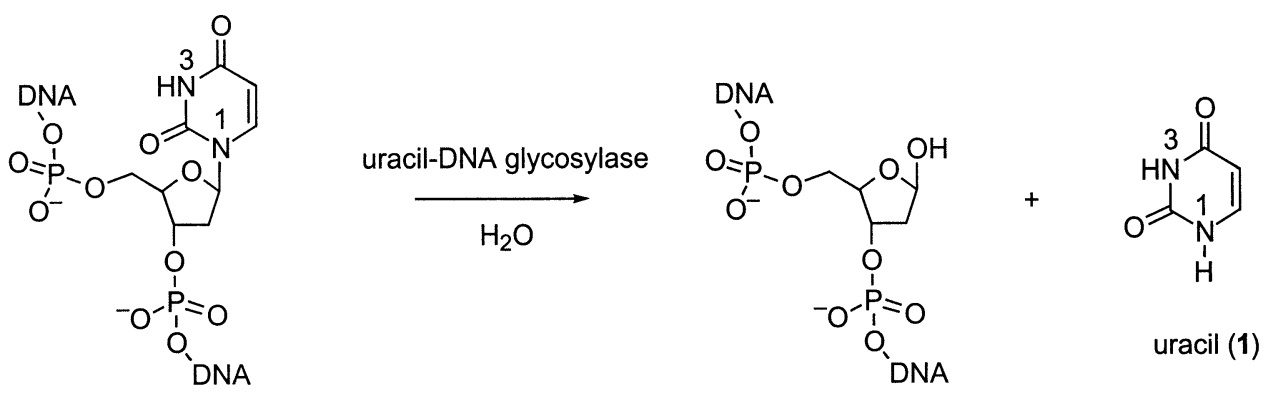

Scheme 1 Uracil cleavage catalyzed by uracil-DNA glycosylase.

UDGase or the $\mathrm{C}^{-}$in ODCase-is made an energetically favorable entity $[4,5,7,19-23,28-60]$.

In earlier work, we examined the acidities of the N1 and $\mathrm{N} 3$ sites of uracil and discovered that the N1 proton is $14 \mathrm{kcal} \mathrm{mol}^{-1}$ more acidic than the N3 proton. This was particularly intriguing in light of the fact that the $\mathrm{N} 1$ and N3 solution-phase $\mathrm{pK}_{\mathrm{a}}{ }^{\prime} \mathrm{s}$ are indistinguishable $[61,62]$. Herein, we describe a more in-depth study of the acidity of pyrimidine nucleobases. We utilize our method for measuring multiple acidic sites on a molecule in an FTMS to establish the acidity of a series of uracil derivatives, and compare those results to calculated values to benchmark the computational methods. Computationally and experimentally, we establish that uracil has four sites more acidic than water in the gas phase. The biological implications of these results, particularly with regard to UDGase and ODCase, are also discussed.

\section{Experimental}

All experiments were conducted on a dual-cell Finnigan 2001 Fourier transform mass spectrometer (Bremen, Germany). Each side of the 2 inch cubic dual cell is pumped down to a baseline pressure of less than $1 \times$ $10^{-9}$ torr. The dual cell is positioned colinearly with the magnetic field produced by a $3.3 \mathrm{~T}$ superconducting magnet.

Neutral samples were introduced into the FT mass spectrometer using a Finnigan heated batch inlet system, a home-built heated batch inlet system, via a pulsed valve system, or by means of a heated solids probe. All chemicals were available commercially and were used as received. Most ions were produced by proton transfer to hydroxide. Hydroxide was generated by pulsing water into the cell and sending an electron beam (typically $6 \mathrm{eV}, 8 \mu \mathrm{A}$, beam time $5 \mathrm{~ms}$ ) through the center of the cell. A trapping potential of $-2 \mathrm{~V}$ was applied to the cell walls perpendicular to the magnetic field at all times except when ions were transferred from one cell to another. Transfer is accomplished by temporarily grounding (50-150 $\mu \mathrm{s})$ the conductance limit plate, the trapping plate separating the two cells. The ions then can pass through a $2 \mathrm{~mm}$ hole in the center of the conductance limit plate. Transferred ions were cooled with argon [63, 64].

Acidity bracketing was utilized to measure the gas phase acidities. Species of known acidities are allowed to react with the substrate of unknown acidity. The ability of the anionic conjugate base of the substrate of unknown acidity to deprotonate relatively stronger acids, and the inability of the anion to deprotonate weaker acids (stronger bases) allow one to bracket the acidity of the unknown. Where possible, the reverse reaction is also explored. Rapid proton transfer (i.e., near the collision rate) was taken as evidence that the reaction was exothermic and is indicated by $\mathrm{a}+$ in the Tables.

We have recently developed a Fourier transform mass spectrometry (FTMS) method, building upon earlier work in the flowing afterglow, for the bracketing of less acidic sites in molecules that have multiple acidic sites; the experimental procedure has been described previously [14, 65-78]. Briefly, using uracil as an example, when hydroxide is used to deprotonate uracil, two ions are formed, the N1-deprotonated uracil and the N3-deprotonated uracil. When the ions are allowed to stay in an environment where there is a constant pressure of neutral uracil, the $\mathrm{N}^{-}$ion isomerizes to $\mathrm{N}^{-}$(Scheme 3). We then transfer the $\mathrm{N}^{-}$ion to the

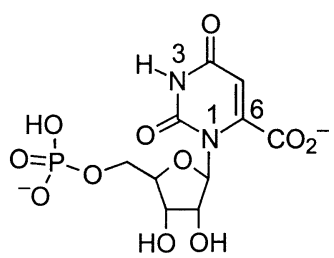

orotate ribose 5'-monophosphate

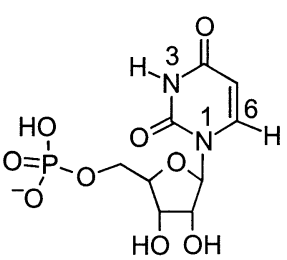

uracil ribose 5'-monophosphate

Scheme 2 Decarboxylation catalyzed by orotidine 5'-monophosphate decarboxylase. 


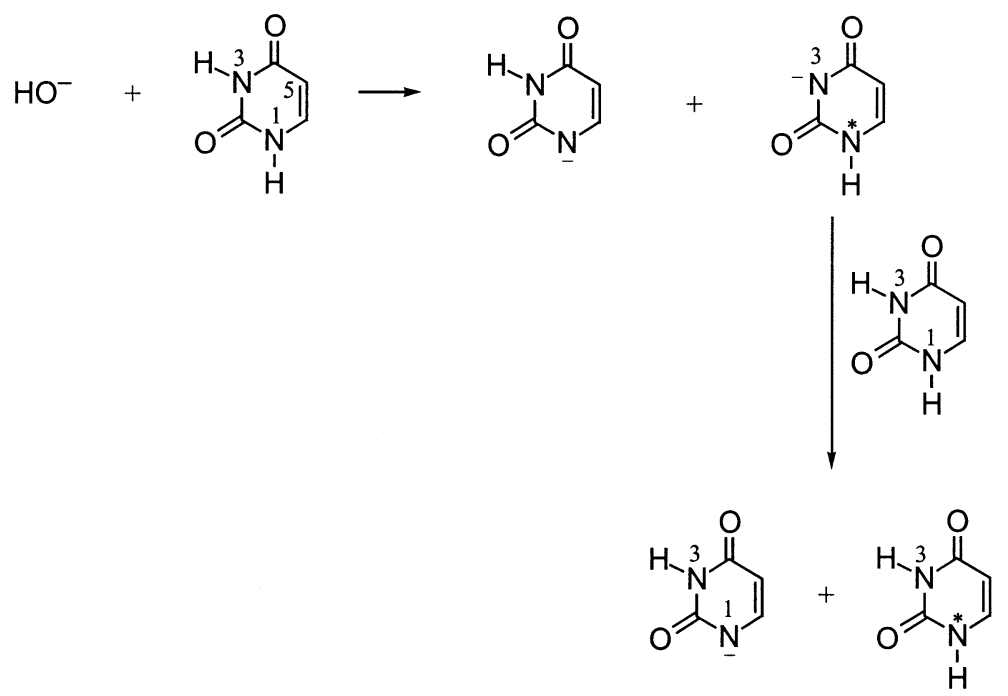

Scheme 3 Uracil-catalyzed isomerization of anion formed from deprotonation of the less acidic N3 site of uracil.

second cell, where the reference acid is added at a constant pressure, and we monitor proton transfer. We refer to these conditions as "more acidic" conditions, because we allow for isomerization to the more acidic site before transfer. If, instead, the $(\mathrm{M}-1)^{-}$of uracil (which is some mixture of $\mathrm{N}^{-}$and $\mathrm{N}^{-}$) is transferred from the neutral uracil environment directly (within 200 $\mathrm{ms}$ ) to the second cell, then the $\mathrm{N}^{-}$will not isomerize and that ion can be bracketed. We will refer to this method as "less acidic" conditions. One experimental caveat, described further in the Discussion, is that when bracketing the less acidic site, Complex 7 in Scheme 4 can partition via either Pathway A or Pathway B. If Pathway B is followed, proton transfer is undetectable. In some cases, deuterated acids can be used to observe both pathways. For example, reaction of a mixture of $\mathrm{N} 1$ and N3 ions with a deuterated acid such as DCOOD results in signal for $\mathrm{A}^{-}$and for $m / z$ 112, described in an earlier paper [14]. Such an experiment also indicates that under these conditions, the less acidic $\mathrm{N}^{-}$ion comprises about $5-10 \%$ of the total $(\mathrm{M}-1)^{-}$signal.

Throughout the text, the term "gas phase acidity" is used to refer to the enthalpic $(\Delta \mathrm{H})$ change associated with deprotonation. Calculations were conducted at<smiles></smiles>

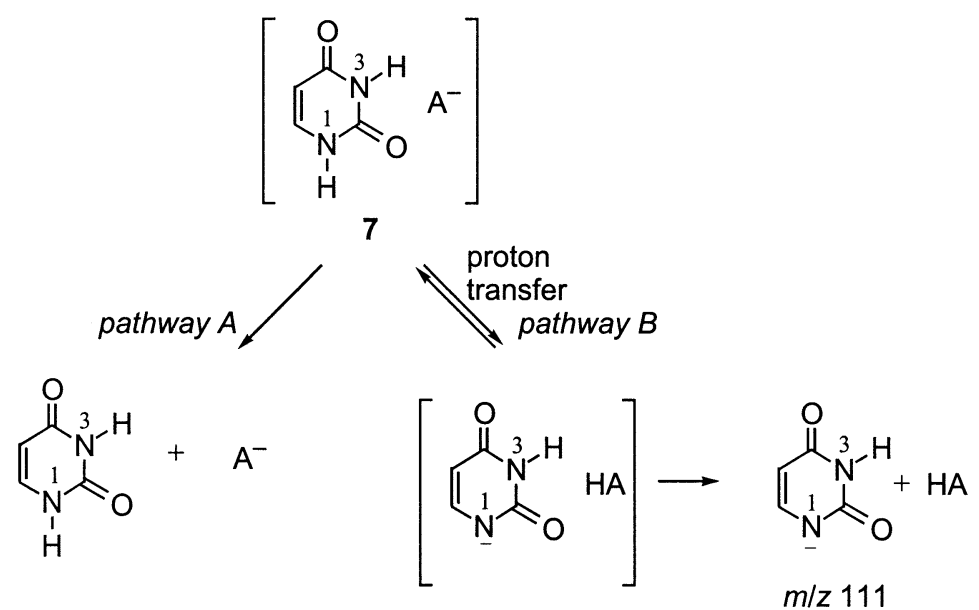

Scheme 4 Possible pathways for bracketing of less acidic site of uracil. 
Table 1. Calculated gas phase acidities of the different sites of uracil, 1-methyluracil, 3-methyluracil, 6-methyluracil, 5,6dimethyluracil, and 1,3-dimethyluracil at B3LYP $/ 6-31+\mathrm{G}^{*}$ in kcal mol ${ }^{-1 \mathrm{a}}$

\begin{tabular}{lcccc}
\hline Structure & $\mathrm{N} 1$ & $\mathrm{~N} 3$ & $\mathrm{C} 5$ & $\mathrm{C6}$ \\
\hline \hline Uracil & 329.0 & 342.6 & 376.1 & 361.5 \\
1-Methyluracil & - & 343.8 & 377.3 & 362.9 \\
3-Methyluracil & 331.3 & - & 378.4 & 363.5 \\
6-Methyluracil & 330.5 & 344.1 & 377.8 & - \\
5,6-Dimethyluracil & 331.7 & 344.6 & - & - \\
1,3-Dimethyluracil & - & - & 378.7 & 365.6
\end{tabular}

${ }^{\mathrm{a} A t} 298 \mathrm{~K}$.

B3LYP/6-31+ $\mathrm{G}^{*}$ using Gaussian94 and Gaussian98 [79, 80]. Frequencies were conducted on all structures and no scaling factor was applied. All acidities reported are at $298 \mathrm{~K}$.

\section{Computational Results}

Calculated acidities for the Compounds 1-6 (uracil, 1-methyluracil, 3-methyluracil, 6-methyluracil, 5,6-dimethyluracil, and 1,3-dimethyluracil) are summarized in Table 1. Calculations were conducted at B3LYP/6$31+\mathrm{G}^{*}$.<smiles>O=c1cccc[nH]1</smiles>

1<smiles>Cc1cc(=O)[nH]c(=O)[nH]1</smiles>

4<smiles></smiles>

2<smiles>Cc1[nH]c(=O)[nH]c(=O)c1C</smiles>

5<smiles>Cn1c(=O)cc[nH]c1=O</smiles>

3

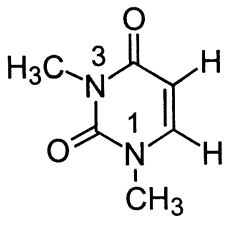

6
Uracil. The calculated values for the acidity of the N1 and N3 sites of uracil are 329.0 and $342.6 \mathrm{kcal} \mathrm{mol}^{-1}$, respectively. Despite solution phase $\mathrm{pK}_{\mathrm{a}}$ 's that are indifferentiable, the gas phase N1 and N3 acidities are calculated to be $13.6 \mathrm{kcal} \mathrm{mol}^{-1}$ apart, with the $\mathrm{N} 1$ site being more acidic. Zeegers-Huyskens et al. have also previously calculated uracil deprotonation energies at B3LYP / 6-31 $++G^{* *}$; these values compare favorably to our numbers (332.5 and $345.8 \mathrm{kcal} \mathrm{mol}^{-1}$ for N1 and N3, respectively) [1].

When considering the acidity of uracil, the $\mathrm{N} 1$ and N3 protons are the most obvious sites. Interestingly, however, the C5 and C6 sites are calculated to be more acidic than might be expected. The predicted $\mathrm{C} 5-\mathrm{H}$ acidity is $376.1 \mathrm{kcal} \mathrm{mol}^{-1}$; the $\mathrm{C} 6-\mathrm{H}$ calculated acidity is 361.5 [81].

1-Methyluracil. This compound is of interest to us because the N1 site is blocked, and experimentally, this will allow us to concentrate on the other remaining acidic sites. There are three potentially acidic sites on 1-methyluracil: N3, C5, and C6. These values are calculated to be quite close to the values of the parent uracil $\left(343.8,377.3,362.9 \mathrm{kcal} \mathrm{mol}^{-1}\right.$, respectively).

3-Methyluracil. As with 1-methyluracil, 3-methyluracil is valuable experimentally, because the 3-position is blocked. 3-Methyluracil has three predicted acidic sites: $\mathrm{N} 1, \mathrm{C} 5$, and $\mathrm{C} 6$; these values are also comparable to those of uracil: $331.3,378.4,363.5 \mathrm{kcal} \mathrm{mol}^{-1}$, respectively.

6-Methyluracil. 6-methyluracil has three acidic sites, $\mathrm{N} 1, \mathrm{~N} 3$, and C5, which are calculated to be 330.5, 344.1, and $377.8 \mathrm{kcal} \mathrm{mol}^{-1}$, comparable to the other uracil derivatives.

5,6-Dimethyluracil. Experimentally useful because only the N1 and N3 can be bracketed, 5,6-dimethyluracil has $\mathrm{N} 1$ and $\mathrm{N} 3$ calculated acidities that are in keeping with the other uracils (331.7 and $344.6 \mathrm{kcal}$ $\mathrm{mol}^{-1}$ ).

1,3-Dimethyluracil. Use of this compound allows us to block both the N1 and N3 sites and concentrate on the lower acidity sites C5 and C6. These sites have calculated acidities of 378.7 and $365.6 \mathrm{kcal} \mathrm{mol}^{-1}$. Our results are also in agreement with calculations by Gronert et al., who calculated the $\mathrm{C} 6$ acidity of 1,3-dimethyluracil at MP2 $/ 6-31+\mathrm{G}^{* *} / / \mathrm{HF} / 6-31+\mathrm{G}^{*}\left(367.6 \mathrm{kcal} \mathrm{mol}^{-1}\right)$ and at B3LYP $/ 6-31+\mathrm{G}^{* *} / / \mathrm{HF} / 6-31+\mathrm{G}^{*}\left(366.0 \mathrm{kcal} \mathrm{mol}^{-1}\right)$ [81].

Calculations predict that methylation changes acidity very little; therefore, these methylated analogs can be used experimentally to establish the validity of the earlier bracketing of the N1 and N3 sites in uracil.

\section{Experimental Results}

Uracil. The N1 and N3 sites of the parent uracil have been bracketed by us previously, to be $333 \pm 4$ and $347 \pm 4 \mathrm{kcal} \mathrm{mol}^{-1}$, respectively [14]. The acidity of uracil has also been measured by Marshall and coworkers, who bracketed the N1-H of uracil; their value is in agreement with ours $\left(\Delta \mathrm{G}_{\text {acid }}=328.9 \pm 0.3 \mathrm{kcal}\right.$ $\mathrm{mol}^{-1}$ ) [82].

1-Methyluracil. The results for the bracketing of 1-methyluracil can be found in Tables 2 and 3 . When we run under conditions in which we should see only the most acidic site (Experimental), we find that the conjugate base of para-trifluoro-aniline $\left(\Delta \mathrm{H}_{\text {acid }}\left[p-\mathrm{CF}_{3} \mathrm{PhNH}_{2}\right]\right.$ 
Table 2. Summary of results of proton transfer from reference acids and bases to 1-methyluracil N3

\begin{tabular}{lccc}
\hline & & \multicolumn{2}{c}{ Proton transfer } \\
\cline { 3 - 4 } Reference compound & $\Delta \mathrm{H}_{\text {acid }}{ }^{\mathrm{b}}$ & $\begin{array}{c}\text { Reference } \\
\text { acid }\end{array}$ & $\begin{array}{c}\text { Conjugate } \\
\text { base }\end{array}$ \\
\hline \hline $\mathrm{HCCl}_{3}$ & $357.6 \pm 2.1$ & - & + \\
$\mathrm{CH}_{3} \mathrm{CHCHCHO}$ & $354.7 \pm 2.1$ & - & + \\
$p-\mathrm{CF}_{3} \mathrm{PhNH}_{2}$ & $353.3 \pm 2.1$ & - & + \\
$\mathrm{CF}_{3} \mathrm{COCH}$ & $349.2 \pm 2.1$ & - & + \\
$\mathrm{CH}_{3} \mathrm{COOH}$ & $348.1 \pm 2.2$ & + & + \\
$\mathrm{HCOOH}$ & $345.3 \pm 2.9$ & + & - \\
\hline
\end{tabular}

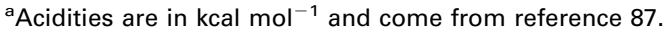

$\mathrm{b}_{+}$Indicates the occurrence; - denotes the absence of proton transfer.

$\left.=353.3 \mathrm{kcal} \mathrm{mol}^{-1}\right)$, the enolate of trifluoroacetone $\left(\Delta \mathrm{H}_{\text {acid }}\left[\mathrm{CF}_{3} \mathrm{COCH}_{3}\right]=349.2 \mathrm{kcal} \mathrm{mol}^{-1}\right)$, and acetate $\left(\Delta \mathrm{H}_{\text {acid }}\left[\mathrm{CH}_{3} \mathrm{COOH}\right]=348.1 \mathrm{kcal} \mathrm{mol}^{-1}\right)$ all deprotonate 1-methyluracil, while formate $\left(\Delta \mathrm{H}_{\text {acid }}[\mathrm{HCOOH}]=\right.$ $345.3 \mathrm{kcal} \mathrm{mol}^{-1}$ ) does not. The conjugate base of 1-methyluracil also deprotonates acetic acid, implying close-to-thermoneutral reactions, since the reactions proceed in both directions. The conjugate base of 1-methyluracil deprotonates formic acid $\left(\Delta \mathrm{H}_{\text {acid }}[\mathrm{H}-\right.$ $\mathrm{COOH}]=345.3 \mathrm{kcal} \mathrm{mol}^{-1}$ ). Based on these results, we bracket the most acidic site of 1-methyluracil to be $348 \pm 3 \mathrm{kcal} \mathrm{mol}^{-1}$.

We can also run under conditions in which the less acidic site(s) is bracketable (Experimental). Under these conditions, we find that the conjugate base of 1-methyluracil can deprotonate 2-fluoroaniline $\left(\Delta \mathrm{H}_{\text {acid }}[m-\mathrm{F}-\right.$ $\left.\left.\mathrm{C}_{6} \mathrm{H}_{6} \mathrm{~N}\right]=362.6 \mathrm{kcal} \mathrm{mol}^{-1}\right)$, but cannot deprotonate 4-fluoroaniline $\left(\Delta \mathrm{H}_{\text {acid }}\left[p-\mathrm{F}-\mathrm{C}_{6} \mathrm{H}_{6} \mathrm{~N}\right]=364.3 \mathrm{kcal} \mathrm{mol}^{-1}\right)$. We therefore bracket only one site under these conditions, with a $\Delta \mathrm{H}_{\text {acid }}$ of $363 \pm 3 \mathrm{kcal} \mathrm{mol}^{-1}$ (Table 3).

3-Methyluracil. Acidity bracketing results for 3-methyluracil are summarized in Tables 4 and 5. The more acidic site of 3-methyluracil brackets to $333 \pm 2 \mathrm{kcal}$ $\mathrm{mol}^{-1}$ (Table 4). Reactions with pyruvic acid $\left(\Delta \mathrm{H}_{\text {acid }}\left[\mathrm{CH}_{3} \mathrm{COCOOH}\right]=333.5 \mathrm{kcal} \mathrm{mol}^{-1}\right)$ and hydrochloric acid $\left(\Delta \mathrm{H}_{\text {acid }}[\mathrm{HCl}]=333.4 \mathrm{kcal} \mathrm{mol}^{-1}\right)$ proceed in both directions. The conjugate base of 3-methyluracil deprotonates difluoroacetic acid $\left(\Delta \mathrm{H}_{\text {acid }}\left[\mathrm{C}_{2} \mathrm{H}_{2} \mathrm{~F}_{2} \mathrm{O}_{2}\right]=\right.$

Table 3. Summary of results of proton transfer from reference acids and bases to 1-methyluracil C6

\begin{tabular}{lcc}
\hline Reference compound & $\Delta \mathrm{H}_{\text {acid }}{ }^{a}$ & $\begin{array}{c}\text { Proton transfer } \\
\text { Reference acid }\end{array}$ \\
\hline \hline $\mathrm{CH}_{3} \mathrm{COCH}_{3}$ & $369.1 \pm 2.1$ & - \\
$\mathrm{CH}_{3} \mathrm{CHO}$ & $365.8 \pm 3.7$ & - \\
4-Fluoroaniline & $364.3 \pm 2.1$ & - \\
2-Fluoroaniline & $362.6 \pm 2.2$ & + \\
Pyrrole & $358.6 \pm 2.2$ & + \\
$\mathrm{CH}_{3} \mathrm{CHCHCHO}$ & $354.7 \pm 2.1$ & + \\
\hline
\end{tabular}

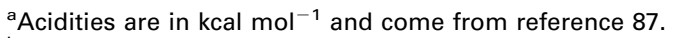

$b_{+}+$Indicates the occurrence; - denotes the absence of proton transfer.
Table 4. Summary or results of proton transfer from reference acids and bases to 3-methyluracil N1

\begin{tabular}{|c|c|c|c|}
\hline \multirow[b]{2}{*}{ Reference compound } & \multirow[b]{2}{*}{$\Delta \mathrm{H}_{\text {acid }}{ }^{\mathrm{a}}$} & \multicolumn{2}{|c|}{ Proton transfer ${ }^{b}$} \\
\hline & & $\begin{array}{l}\text { Reference } \\
\text { acid }\end{array}$ & $\begin{array}{c}\text { Conjugate } \\
\text { base }\end{array}$ \\
\hline $\mathrm{CH}_{3} \mathrm{COCH}_{3}$ & $369.1 \pm 2.1$ & - & + \\
\hline $\mathrm{CF}_{3} \mathrm{COCH}_{3}$ & $349.2 \pm 2.1$ & - & + \\
\hline $\mathrm{CH}_{3} \mathrm{COOH}$ & $348.1 \pm 2.1$ & - & + \\
\hline $\mathrm{HCOOH}$ & $345.3 \pm 2.9$ & - & + \\
\hline $\mathrm{CH}_{3} \mathrm{COCH}_{2} \mathrm{COCH}_{3}$ & $343.8 \pm 2.1$ & - & + \\
\hline$m-\mathrm{CF}_{3} \mathrm{PhOH}$ & $339.3 \pm 2.1$ & - & + \\
\hline $\mathrm{CH}_{3} \mathrm{CHClCOOH}$ & $337.0 \pm 2.1$ & - & + \\
\hline $\mathrm{CH}_{3} \mathrm{COCOOH}$ & $333.5 \pm 2.9$ & + & + \\
\hline $\mathrm{HCl}$ & $333.4 \pm 0.1$ & + & + \\
\hline $\mathrm{CHF}_{2} \mathrm{COOH}$ & $331.0 \pm 2.1$ & + & - \\
\hline $\mathrm{CF}_{3} \mathrm{COCH}_{2} \mathrm{COCH}_{3}$ & $328.3 \pm 2.9$ & + & - \\
\hline
\end{tabular}

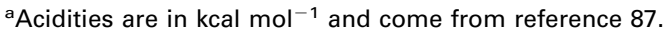

$\mathrm{b}_{+}$Indicates the occurrence; - denotes the absence of proton transfer.

$331.0 \mathrm{kcal} \mathrm{mol}^{-1}$ ) but difluoroacetate does not deprotonate 3-methyluracil.

The less acidic site of 3-methyluracil was bracketed as shown in Table 5. Under "less acidic" conditions, the conjugate base of 3-methyluracil deprotonates 2fluoroaniline $\left(\Delta \mathrm{H}_{\text {acid }}\left[m-\mathrm{F}-\mathrm{C}_{6} \mathrm{H}_{6} \mathrm{~N}\right]=362.6 \mathrm{kcal} \mathrm{mol}^{-1}\right)$ but does not deprotonate 4 -fluoroaniline $\left(\Delta \mathrm{H}_{\text {acid }}[p-\mathrm{F}-\right.$ $\left.\left.\mathrm{C}_{6} \mathrm{H}_{6} \mathrm{~N}\right]=364.3 \mathrm{kcal} \mathrm{mol}^{-1}\right)$. We therefore bracket this site to be $363 \pm 3 \mathrm{kcal} \mathrm{mol}^{-1}$.

6-Methyluracil. The conjugate base of 6-methyluracil deprotonates difluoroacetic acid $\left(\Delta \mathrm{H}_{\text {acid }}\left[\mathrm{C}_{2} \mathrm{H}_{2} \mathrm{~F}_{2} \mathrm{O}_{2}\right]=\right.$

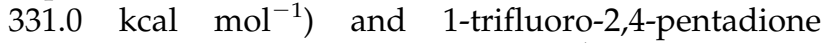
$\left(\Delta \mathrm{H}_{\text {acid }}\left[\mathrm{C}_{5} \mathrm{H}_{5} \mathrm{~F}_{3} \mathrm{O}_{2}\right]=328.3 \mathrm{kcal} \mathrm{mol}^{-1}\right)$, but does not deprotonate $\mathrm{HCl}\left(\Delta \mathrm{H}_{\text {acid }}[\mathrm{HCl}]=333.4 \mathrm{kcal} \mathrm{mol}^{-1}\right) \cdot \mathrm{Cl}^{-}$ is also able to deprotonate 6-methyluracil. We therefore bracket the more acidic site of 6-methyluracil to be $331 \pm 3 \mathrm{kcal} \mathrm{mol}^{-1}$ (Table 6).

The more basic conjugate base of 6-methyluracil does not deprotonate crotonaldehyde $\left(\Delta \mathrm{H}_{\text {acid }}\left[\mathrm{C}_{4} \mathrm{H}_{6} \mathrm{O}_{2}\right]=\right.$ $354.7 \mathrm{kcal} \mathrm{mol}^{-1}$, Table 7), but is able to deprotonate trifluoroacetone $\left(\Delta \mathrm{H}_{\text {acid }}\left[\mathrm{C}_{3} \mathrm{H}_{3} \mathrm{~F}_{3} \mathrm{O}\right]=349.2 \mathrm{kcal} \mathrm{mol}^{-1}\right)$. We therefore bracket the less acidic site of 6-methyluracil to be $352 \pm 5 \mathrm{kcal} \mathrm{mol}^{-1}$.

Table 5. Summary of results of proton transfer from reference acids and bases to 3-methyluracil C6

\begin{tabular}{lcc}
\hline Reference compound & $\Delta \mathrm{H}_{\text {acid }}{ }^{a}$ & $\begin{array}{c}\text { Proton transfer } \\
\text { reference acid }\end{array}$ \\
\hline \hline $\mathrm{CH}_{3} \mathrm{COCH}_{3}$ & $369.1 \pm 2.1$ & - \\
$\mathrm{CH}_{3} \mathrm{CHO}$ & $365.8 \pm 3.7$ & - \\
4-Fluoroaniline & $364.3 \pm 2.1$ & - \\
2-Fluoroaniline & $362.6 \pm 2.2$ & + \\
Pyrrole & $358.6 \pm 2.2$ & + \\
$\mathrm{CH}_{3} \mathrm{COOH}$ & $348.1 \pm 2.1$ & + \\
$\mathrm{HCOOH}$ & $345.3 \pm 2.1$ & + \\
\hline
\end{tabular}

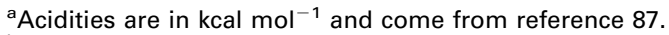

$b_{+}$Indicates the occurrence; - denotes the absence of proton transfer. 
Table 6. Summary of results of proton transfer from reference acids and bases to 6-methyluracil N1

\begin{tabular}{lccc}
\hline & & \multicolumn{2}{c}{ Proton transfer ${ }^{\mathbf{b}}$} \\
\cline { 3 - 4 } Reference compound & $\Delta \mathrm{H}_{\text {acid }}{ }^{a}$ & $\begin{array}{c}\text { Reference } \\
\text { acid }\end{array}$ & $\begin{array}{c}\text { Conjugate } \\
\text { base }\end{array}$ \\
\hline \hline $\mathrm{CH}_{3} \mathrm{COCH}_{2} \mathrm{COCH}_{3}$ & $343.8 \pm 2.1$ & - & + \\
$m-\mathrm{CF}_{3} \mathrm{PhOH}$ & $339.3 \pm 2.1$ & - & + \\
$\mathrm{CH}_{3} \mathrm{COCOOH}$ & $333.5 \pm 2.9$ & - & + \\
$\mathrm{HCl}_{\mathrm{CHF}_{2} \mathrm{COOH}}$ & $333.4 \pm 0.1$ & - & + \\
$\mathrm{CF}_{3} \mathrm{COCH}_{2} \mathrm{COCH}_{3}$ & $331.0 \pm 2.1$ & + & + \\
\hline
\end{tabular}

acidities are in $\mathrm{kcal} \mathrm{mol}^{-1}$ and come from reference 87.

$\mathbf{b}_{+}$Indicates the occurrence; - denotes the absence of proton transfer.

5,6-Dimethyluracil. The results for the bracketing studies of the more acidic site of 5,6-dimethyluracil are summarized in Table 8. Reactions with pyruvic acid $\left(\Delta \mathrm{H}_{\text {acid }}\left[\mathrm{CH}_{3} \mathrm{COCOOH}\right]=333.5 \mathrm{kcal} \mathrm{mol}^{-1}\right)$ and hydrochloric acid $\left(\Delta \mathrm{H}_{\text {acid }}[\mathrm{HCl}]=333.4 \mathrm{kcal} \mathrm{mol}^{-1}\right)$ proceed in both directions. The conjugate base of 5,6-dimethyluracil deprotonates trifluoropentadione $\left(\Delta \mathrm{H}_{\text {acid }}\left[\mathrm{CF}_{3} \mathrm{COCH}_{2} \mathrm{COCH}_{3}\right]=328.3 \mathrm{kcal} \mathrm{mol}^{-1}\right)$, but the enolate of the pentadione does not deprotonate 5,6-dimethyluracil. We therefore bracket the most acidic site of 5,6-dimethyluracil to be $333 \pm 2 \mathrm{kcal} \mathrm{mol}^{-1}$.

The less acidic site of 5,6-dimethyluracil brackets to

Table 7. Summary of results of proton transfer from reference acids and bases to 6-methyluracil N3

\begin{tabular}{|c|c|c|}
\hline Reference compound & $\Delta \mathrm{H}_{\text {acid }}{ }^{\mathrm{a}}$ & $\begin{array}{c}\text { Proton transfer } \\
\text { reference acid } \\
\end{array}$ \\
\hline Pyrrole & $358.6 \pm 2.2$ & - \\
\hline $\mathrm{CH}_{3} \mathrm{CD}_{2} \mathrm{NO}_{2}$ & $355.9 \pm 2.2$ & - \\
\hline $\mathrm{CH}_{3} \mathrm{CHCHCHO}$ & $354.7 \pm 2.1$ & - \\
\hline $\mathrm{CF}_{3} \mathrm{COCH}_{3}$ & $349.2 \pm 2.1$ & + \\
\hline $\mathrm{CH}_{3} \mathrm{COOH}$ & $348.1 \pm 2.1$ & + \\
\hline $\mathrm{HCOOH}$ & $345.3 \pm 2.1$ & + \\
\hline $\mathrm{CH}_{3} \mathrm{COCH}_{2} \mathrm{COCH}_{3}$ & $343.8 \pm 2.1$ & + \\
\hline$m-\mathrm{CF}_{3} \mathrm{PhOH}$ & $339.3 \pm 2.1$ & + \\
\hline
\end{tabular}

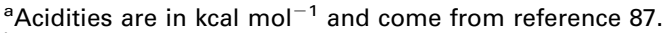

$b_{+}$Indicates the occurrence; - denotes the absence of proton transfer.

Table 8. Summary of results of proton transfer from reference acids and bases to 5,6-dimethyluracil N1

\begin{tabular}{lccc}
\hline & & \multicolumn{2}{c}{ Proton transfer $^{\mathrm{b}}$} \\
\cline { 3 - 4 } Reference compound & $\Delta \mathrm{H}_{\text {acid }}{ }^{\text {a }}$ & $\begin{array}{c}\text { Reference } \\
\text { acid }\end{array}$ & $\begin{array}{c}\text { Conjugate } \\
\text { base }\end{array}$ \\
\hline \hline $\mathrm{CF}_{3} \mathrm{COCH}_{3}$ & $349.2 \pm 2.1$ & - & + \\
$\mathrm{CH}_{3} \mathrm{COOH}$ & $348.1 \pm 2.1$ & - & + \\
$\mathrm{HCOOH}_{\mathrm{CH}_{3} \mathrm{COCH}} \mathrm{COCH}_{3}$ & $345.3 \pm 2.2$ & - & + \\
$m_{-} \mathrm{CF}_{3} \mathrm{PhOH}$ & $339.3 \pm 2.1$ & - & + \\
$\mathrm{CH}_{3} \mathrm{COCOOH}$ & $333.5 \pm 2.9$ & - & + \\
$\mathrm{HCl}$ & $333.4 \pm 0.1$ & + & + \\
$\mathrm{CF}_{3} \mathrm{COCH}_{2} \mathrm{COCH}_{3}$ & $328.3 \pm 2.1$ & + & + \\
\hline
\end{tabular}

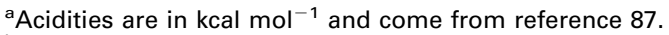

$\mathrm{b}_{+}$Indicates the occurrence; - denotes the absence of proton transfer.
Table 9. Summary of results of proton transfer from reference acids and bases to 5,6-dimethyluracil N3

\begin{tabular}{lcc}
\hline Reference compound & $\Delta \mathrm{H}_{\text {acid }}{ }^{\text {a }}$ & $\begin{array}{c}\text { Proton transfer } \\
\text { Reference acid }\end{array}$ \\
\hline \hline $\mathrm{CH}_{3} \mathrm{CHCHCHO}$ & $354.7 \pm 2.1$ & - \\
$\mathrm{CF}_{3} \mathrm{COCH}$ & $349.2 \pm 2.1$ & - \\
$\mathrm{CH}_{3} \mathrm{COOH}$ & $348.1 \pm 2.2$ & + \\
$\mathrm{HCOOH}$ & $345.3 \pm 2.9$ & + \\
$\mathrm{CH}_{3} \mathrm{COCH} \mathrm{COCH}_{3}$ & $343.8 \pm 2.1$ & + \\
$m-\mathrm{CF}_{3} \mathrm{PhOH}$ & $339.3 \pm 2.1$ & + \\
\hline
\end{tabular}

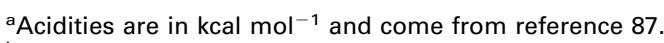

$\mathrm{b}_{+}$Indicates the occurrence; - denotes the absence of proton transfer.

$349 \pm 3 \mathrm{kcal} \mathrm{mol}^{-1}$. While the conjugate base of 5,6-dimethyluracil is unable to deprotonate trifluoroacetone $\left(\Delta \mathrm{H}_{\text {acid }}\left[\mathrm{C}_{3} \mathrm{H}_{3} \mathrm{~F}_{3} \mathrm{O}\right]=349.2 \mathrm{kcal} \mathrm{mol}^{-1}\right)$, it does deprotonate acetic acid $\left(\Delta \mathrm{H}_{\text {acid }}\left[\mathrm{C}_{2} \mathrm{H}_{4} \mathrm{O}_{2}\right]=348.1 \mathrm{kcal}\right.$ $\mathrm{mol}^{-1}$, Table 9).

1,3-Dimethyluracil. The more acidic site of 1,3-dimethyluracil was bracketed as shown in Table 10. The conjugate bases of 2-fluoroethanol $\left(\Delta \mathrm{H}_{\text {acid }}\left[\mathrm{C}_{3} \mathrm{H}_{5} \mathrm{FO}\right]=\right.$ $\left.371.2 \mathrm{kcal} \mathrm{mol}^{-1}\right)$ and acetone $\left(\Delta \mathrm{H}_{\text {acid }}\left[\mathrm{C}_{3} \mathrm{H}_{6} \mathrm{O}\right]=369.1\right.$ $\mathrm{kcal} \mathrm{mol}^{-1}$ ) deprotonate 1,3-dimethyluracil, but the enolate of 3-pentanone $\left(\Delta \mathrm{H}_{\text {acid }}\left[\mathrm{C}_{5} \mathrm{H}_{10} \mathrm{O}\right]=368.6 \mathrm{kcal} \mathrm{mol}^{-1}\right)$ does not. The conjugate base of 1,3-dimethyluracil does not deprotonate acetone, but does deprotonate 3-pentanone. Based on these results, we bracket the more acidic site of 1,3-dimethyluracil to be $369 \pm 2 \mathrm{kcal} \mathrm{mol}^{-1}$.

The results for the bracketing of the less acidic site of 1,3-dimethyluracil are summarized in Table 11. While the conjugate base of 1,3-dimethyluracil deprotonates methanol $\left(\Delta \mathrm{H}_{\text {acid }}\left[\mathrm{CH}_{3} \mathrm{O}\right]=381.8 \mathrm{kcal} \mathrm{mol}^{-1}\right)$, it cannot deprotonate 2-methylfuran $\left(\Delta \mathrm{H}_{\text {acid }}\left[\mathrm{C}_{5} \mathrm{H}_{6} \mathrm{O}\right]=383.9\right.$ $\mathrm{kcal} \mathrm{mol}^{-1}$ ). This less acidic site brackets to $384 \pm 3 \mathrm{kcal}$ $\mathrm{mol}^{-1}$.

Table 10. Summary of results of proton transfer from reference acids and bases to 1,3-dimethyluracil C6

\begin{tabular}{lccc}
\hline & & \multicolumn{2}{c}{ Proton transfer } \\
\cline { 3 - 4 } Reference compound & $\Delta \mathrm{H}_{\text {acid }}{ }^{\text {a }}$ & $\begin{array}{c}\text { Reference } \\
\text { acid }\end{array}$ & $\begin{array}{c}\text { Conjugate } \\
\text { base }\end{array}$ \\
\hline \hline $\mathrm{C}\left(\mathrm{CH}_{3}\right)_{3} \mathrm{CHO}$ & $387.4 \pm 4.1$ & - & + \\
cyclohexene & $386.5 \pm 5.1$ & - & + \\
$\mathrm{CH}_{2} \mathrm{CHC}\left(\mathrm{CH}_{3}\right) \mathrm{CH}_{2}$ & $385.6 \pm 5.1$ & - & + \\
$\mathrm{CH}_{3} \mathrm{OH}$ & $381.8 \pm 1.0$ & - & + \\
$\mathrm{CH}_{3} \mathrm{CH}_{2} \mathrm{OH}$ & $378.3 \pm 1.0$ & - & + \\
$\mathrm{CH}\left(\mathrm{CH}_{3}\right)_{2} \mathrm{OH}$ & $375.9 \pm 1.2$ & - & + \\
$\mathrm{CH}_{2} \mathrm{CHCH}_{2} \mathrm{OH}$ & $373.5 \pm 2.9$ & - & + \\
$\mathrm{CH}_{2} \mathrm{FCH}_{2} \mathrm{OH}$ & $371.2 \pm 2.9$ & - & + \\
$\mathrm{CH}_{3} \mathrm{COCH}_{3}$ & $369.1 \pm 2.1$ & - & + \\
$\mathrm{CH}_{3} \mathrm{CH}_{2} \mathrm{COCH}_{2} \mathrm{CH}_{3}$ & $368.6 \pm 2.2$ & + & - \\
$\mathrm{CH}_{3} \mathrm{COCH}_{2} \mathrm{CH}_{3}$ & $367.2 \pm 2.4$ & + & - \\
$\mathrm{CH}_{3} \mathrm{CHO}_{2-\mathrm{HO}}$ & $365.8 \pm 3.7$ & + & - \\
$2-\mathrm{Fluoroaniline}$ & $362.6 \pm 2.2$ & + & - \\
$\mathrm{Pyrrole}$ & $358.6 \pm 2.2$ & + & - \\
\hline
\end{tabular}

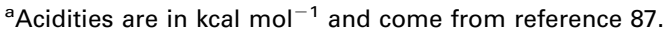

$b_{+}$Indicates the occurrence; - denotes the absence of proton transfer. 
Table 11. Summary of results of proton transfer from reference acids and bases to 1,3-dimethyluracil C5

\begin{tabular}{lcc}
\hline $\begin{array}{l}\text { Reference } \\
\text { compound }\end{array}$ & $\Delta \mathrm{H}_{\text {acid }}{ }^{\mathrm{a}}$ & $\begin{array}{c}\text { Proton transfer } \\
\text { Reference acid }\end{array}$ \\
\hline \hline $\mathrm{CH}_{3} \mathrm{C}\left(\mathrm{CH}_{2}\right) \mathrm{C}\left(\mathrm{CH}_{2}\right) \mathrm{CH}_{3}$ & $388.1 \pm 2.1$ & - \\
$\mathrm{Cyclohexene}_{\mathrm{CH}} \mathrm{CHC}\left(\mathrm{CH}_{3}\right) \mathrm{CH}_{2}$ & $386.5 \pm 5.1$ & - \\
2-Methylfuran & $385.6 \pm 5.1$ & - \\
$\mathrm{CH}_{3} \mathrm{OH}$ & $383.9 \pm 3.1$ & - \\
$\mathrm{CH}_{3} \mathrm{CH}_{2} \mathrm{OH}$ & $381.8 \pm 1.0$ & + \\
$\mathrm{CH}\left(\mathrm{CH}_{3}\right)_{2} \mathrm{OH}$ & $378.3 \pm 1.0$ & + \\
\hline
\end{tabular}

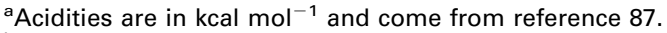

$b_{+}$Indicates the occurrence; - denotes the absence of proton transfer.

\section{Discussion}

A summary of the experimental results for the compounds in this study are in Table 12, with assignations of the site that is believed to have been measured. Corresponding calculated values, computed at B3LYP/6$31+\mathrm{G}^{*}$, are in parentheses. The calculations and experimental data are in agreement, within experimental error. $\mathrm{B} 3 \mathrm{LYP} / 6-31+\mathrm{G}^{*}$ therefore appears to be a reasonable method and level at which to calculate gas-phase enthalpies of deprotonation of nucleobases [1, 2, 14, 81, 83-85].

N1 and N3 acidities. The acidity of uracil is of particular interest because it impacts directly on issues of biological relevance. In solution, the N1 and N3 acidities of uracil are indistinguishable [61, 62]. Measuring the acidity of uracil yields a $\mathrm{pK}_{\mathrm{a}}$ of 9.5 , a mixture of $\mathrm{N} 1$ and N3 deprotonation. 3-Methyluracil has a $\mathrm{pK}_{\mathrm{a}}$ of 10.0, while 1-methyluracil has a $\mathrm{pK}_{\mathrm{a}}$ of 9.8. The fact that the acidities are indistinguishable is of interest since glycosylation of a nucleobase to make a nucleic acid takes place specifically at N1; the sites should be similarly reactive, yet nature glycosylates specifically at N1. Also of interest is the deglycosylation of uracil, which is effected by UDGase (Scheme 1). The mechanism appears to involve some form of N1-deprotonated uracil as a leaving group; however, because uracil has a relatively high $\mathrm{pK}_{\mathrm{a}}$, deprotonated uracil should be a mediocre leaving group and mechanistic hypotheses have focussed on ways in which the uracil could be activated to encourage its leaving group ability $[4,5,19-23]$.
Intriguingly, although the $\mathrm{N} 1$ and $\mathrm{N} 3$ acidities of uracil are indifferentiable in solution, calculations predict they should be $13.6 \mathrm{kcal} \mathrm{mol}^{-1}$ apart in the gas phase $[1,14]$. Measurement of the parent uracil under our "more acidic" and "less acidic" conditions are in agreement with these calculations (N1-H, $333 \mathrm{kcal}$ $\mathrm{mol}^{-1}$, N3-H, $347 \mathrm{kcal} \mathrm{mol}^{-1}$, Table 12) [14]. However, measurement of a less acidic site is, by virtue of the experiment, somewhat limited. First, the reaction can only be conducted in one direction; with uracil, that is $\mathrm{N} 3^{-}$plus reference acids (HA). Second, the formation of the [uracil N3 ${ }^{-}$. HA] complex followed by proton transfer results in ion molecule Complex 7 (Scheme 4). Complex 7 can partition in two ways: The complex can separate, thus producing a signal for $\mathrm{A}^{-}$that indicates proton transfer; or, $\mathrm{A}^{-}$can deprotonate the $\mathrm{N} 1-\mathrm{H}$ of uracil, which simply yields the $[\mathrm{M}-\mathrm{H}]^{-}$of uracil, which is indistinguishable from the starting anion at $\mathrm{m} / \mathrm{z}$ 111. Should the ion-molecule Complex 7 "choose" to take the latter pathway exclusively, it will appear that proton transfer does not take place, which is an experimental caveat. One motivation, therefore, for the study of the methylated analogs of uracil is to block more acidic sites to measure less acidic sites, and confirm the measurements of the parent uracil [67-69].

Calculations predict that methylation should affect acidities very little. For example, while uracil N1 has a predicted deprotonation enthalpy of $329 \mathrm{kcal} \mathrm{mol}^{-1}$, 3-methyluracil N1-H is calculated to be $331 \mathrm{kcal} \mathrm{mol}^{-1}$. Although differing by $2 \mathrm{kcal} \mathrm{mol}^{-1}$, certainly $\mathrm{N} 1$ is still nowhere near the less acidic site, N3. The N3-H of the parent uracil has a calculated acidity of $343 \mathrm{kcal} \mathrm{mol}^{-1}$, while the N3-H of 1-methyluracil (which conveniently blocks the more acidic N1 site) is calculated to be $344 \mathrm{kcal}$ $\mathrm{mol}^{-1}$.

Experimentally, the methylated analogs behave as predicted. The N1-H of 3-methyluracil brackets to 333 $\mathrm{kcal} \mathrm{mol}^{-1}$, while the N3-H of 1-methyluracil brackets to $348 \mathrm{kcal} \mathrm{mol}^{-1}$, comparable to the N1 and N3 protons in the parent uracil (333 and $347 \mathrm{kcal} \mathrm{mol}^{-1}$, respectively). Among all the analogs with an available N1 proton, the N1-H acidities bracket to between 331-333 kcal $\mathrm{mol}^{-1}$, and are essentially the same within experimental error. The N3 sites bracket to 347-352 $\mathrm{kcal} \mathrm{mol}^{-1}$. Therefore, there is indeed a disparity between the N1

Table 12. Summary of experimental and calculated gas phase acidities of the different sites of uracil, 1-methyluracil, 3-methyluracil, 6-methyluracil, 5,6-dimethyluracil, and 1,3-dimethyluracil, in $\mathrm{kcal} \mathrm{mol}^{-1 \mathrm{a}, \mathrm{b}, \mathrm{c}}$

\begin{tabular}{lcccc}
\hline Structure & N1 & N3 & C5 & C6 \\
\hline \hline Uracil & $333 \pm 4(329.0)$ & $347 \pm 4(342.6)$ & NM (376.1) & NM (361.5) \\
1-Methyluracil & NA & $348 \pm 3(343.8)$ & NM (377.3) & $363 \pm 3(362.9)$ \\
3-Methyluracil & $333 \pm 2(331.3)$ & NA & NM (378.4) & $363 \pm 3(363.5)$ \\
6-Methyluracil & $331 \pm 3(330.5)$ & $352 \pm 5(344.1)$ & NM (377.8) & NA \\
5,6-Dimethyluracil & $333 \pm 2(331.7)$ & $349 \pm 3(344.6)$ & NA & NA \\
1,3-Dimethyluracil & NA & NA & $384 \pm 3(378.7)$ & $369 \pm 2(365.6)$ \\
\hline
\end{tabular}

aValues in parentheses are calculated at $298 \mathrm{~K}$ at $\mathrm{B} 3 \mathrm{LYP} / 6-31+\mathrm{G}^{*}$.

bNA is not applicable (site is alkylated).

${ }^{\mathrm{c} N M}$ is not measured (see text). 
and N3 acidities in the gas phase, and solvation causes these acidities to coalesce. Nature may take advantage of this differential acidity in a nonpolar environment such as an enzyme active site to glycosylate specifically at N1. Furthermore, our results show that N1-deprotonated uracil may not be a poor leaving group in the gas phase; its proton affinity is the same as that of chloride. Therefore, in a nonpolar cavity, N1-deprotonated uracil may be easier to cleave than the solution phase $\mathrm{pK}_{\mathrm{a}} \mathrm{s}$ imply. In keeping with our predictions, recent experimental studies with UDGase indicate that the anionic base is most probably a leaving group, contrary to previous hypotheses that involved protonation of the uracil before cleavage [22, 31-33].

C5 and C6 acidities. Through these studies, we have also found that the N1 and N3 sites are not the only positions of relatively high acidity. Uracil has four potentially acidic sites, the $\mathrm{N} 1$, the $\mathrm{N} 3$, the $\mathrm{C} 5$, and the C6. Calculations predict that the $\mathrm{C} 5$ and $\mathrm{C} 6$ positions will have acidities of 376.1 and $361.5 \mathrm{kcal} \mathrm{mol}^{-1}$, respectively. Our experimental results are in agreement with computational predictions (Table 12); the $\mathrm{C} 6$ in 1-methyluracil and 3-methyluracil brackets to $363 \mathrm{kcal}$ $\mathrm{mol}^{-1}$, and $369 \mathrm{kcal} \mathrm{mol}^{-1}$ in 1,3-dimethyluracil. The C5 of 1,3-dimethyluracil brackets to $384 \mathrm{kcal} \mathrm{mol}^{-1}$. Our results are also consistent with earlier work by Gronert et. al, who bracketed the C6 site of 1,3-dimethyluracil (via decarboxylation of orotate in Structure 8) to be $369.9 \pm 3.1 \mathrm{kcal} \mathrm{mol}^{-1}[81]$.

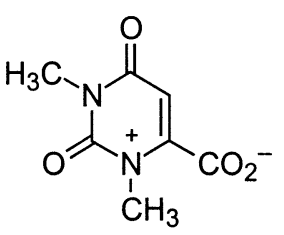

8

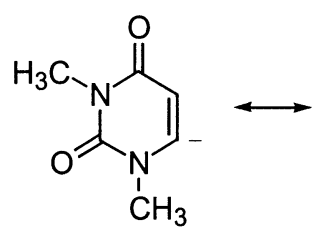

resonance Structure 9, a carbene-ylide [7, 49, 60]. The C5 anion, with a calculated proton affinity of $376 \mathrm{kcal} \mathrm{mol}^{-1}$, is comparable in proton affinity to the conjugate base of acrolein. The present work establishes experimentally the stability of the C6 ion, as manifested by its acidity. Interestingly, the transformation of orotate to uracil is the only known biochemical decarboxylation where the resultant anion has no pi system into which to delocalize. Our results establish that, despite its lack of pi stabilization, the resultant $\mathrm{C} 6$ anion is not as unfavorable in a nonpolar environment as one might initially think, despite its lack of pi stabilization, which may be related to catalysis by ODCase.

Kinetic effects. We have found that for each uracil analog, we are able to bracket the acidities of the two most acidic positions. Therefore, although hydroxide $\left(\Delta \mathrm{H}_{\text {acid }}=390.7 \mathrm{kcal} \mathrm{mol}^{-1}\right)$ is sufficiently basic to deprotonate all four sites of uracil, we bracket only the $\mathrm{N} 1$ and the N3 sites, not the C5 and the C6. Likewise, with 1-methyluracil we bracket only the N3 and C6 sites, although the $\mathrm{C} 5$ site has a proton; with 3-methyluracil we bracket $\mathrm{N} 1$ and $\mathrm{C} 6$, not $\mathrm{C} 5$; the pattern continues with all the uracils.

We initially speculated that the issue might be one of ion mobility, which has been observed in the reaction of deuterated reagents with $p$-difluorophenyl anions [88]. For example, with uracil, perhaps the $\mathrm{N}^{-}$reacts mostly via Pathway A in Scheme 4, whereas the $\mathrm{C}^{-}$and $\mathrm{C}^{-}$ ions react primarily via Pathway B and therefore cannot
The vinylic protons of acrolein calculate to 382.6 (terminal) and 374.5 (adjacent to carbonyl) $\mathrm{kcal} \mathrm{mol}^{-1}$, and the acidity of pyridine is $391 \mathrm{kcal} \mathrm{mol}^{-1}$ [86, 87]. The C6 proton of uracil therefore does appear to be unusually acidic. This anion is of particular biological interest, because the final step in the de novo synthesis of pyrimidine nucleotides involves decarboxylation of orotate ribose 5'-monophosphate to ultimately yield uracil ribose 5'-monophosphate, presumably via some form of the $\mathrm{C} 6$ anion as an intermediate (Scheme 2). The reaction is catalyzed by orotidine 5'-monophosphate decarboxylase, a key antitumor target, via a mechanism that is hotly debated. The nature of the C6 anionic intermediate resulting from decarboxylation of orotate is of course the focus of mechanistic studies-how stable is it, and how does the enzyme catalyze the reaction? We have established, through earlier computational studies, that the $\mathrm{C} 6$ anion may garner special stability because of its be bracketed. One possible reason for this difference in behavior is that after the $\mathrm{N}^{-}$accepts a proton, the resultant conjugate base may not be mobile enough to move easily past the 2-carbonyl and around the ring and deprotonate the N1 site (that is, Pathway B could be somewhat suppressed). If this were true, however, presumably, the C6 in 3-methyluracil should not be bracketable, but it is. More likely, our bracketing only the two most acidic sites of each uracil is a kinetic effect. Hydroxide probably removes the proton from the third least acidic site most infrequently [65, 66]. Additionally, the anion formed from the least acidic site will be particularly prone to isomerization, because there are two or more sites with which it could react. For example, with 3-methyluracil, there are three potentially acidic sites, the $\mathrm{N} 1$, the $\mathrm{C} 5$, and the C6. Reaction with hydroxide should result in the least amount of $\mathrm{C}^{-}$. Because there is so little of $\mathrm{C}^{-}$, it will be a difficult position to bracket. In addition, 
the $\mathrm{C}^{-}$will also rearrange readily to the $\mathrm{N}^{-}$and the $\mathrm{C} 6^{-}$ ions, which will further decrease odds of bracketing the C5 position. We believe that these two effects-minimal formation of the $\mathrm{C}^{-}$and facile isomerization to $\mathrm{N}^{-}$and $\mathrm{C6}^{-}$- make bracketing the third and fourth least acidic sites in a molecule improbable.

\section{Conclusions}

We have discovered that uracil has four surprisingly acidic sites. Calculations and experiments indicate that methylation is an effective means of targeting specific sites for acidity bracketing. Among all the uracil analogs, the N1-H acidities bracket to between 331-333 kcal $\mathrm{mol}^{-1}$. The N3 sites all bracket to 347-352 $\mathrm{kcal} \mathrm{mol}^{-1}$. The C6 in 1-methyluracil and 3-methyluracil brackets to $363 \mathrm{kcal} \mathrm{mol}^{-1}$, and $369 \mathrm{kcal} \mathrm{mol}^{-1}$ in 1,3-dimethyluracil. The C5 of 1,3-dimethyluracil brackets to $384 \mathrm{kcal}$ $\mathrm{mol}^{-1}$. The $\mathrm{C} 6$ carbon vinylic site is particularly acidic with respect to acrolein and pyridine, which has implications with regard to ODCase. The relatively stability of the $\mathrm{C} 6^{-}$means that decarboxylation of orotate to form uracil in a nonpolar environment is more facile than might be expected, which might constitute an enzymatic advantage. The measured gas phase N1 and N3 acidities are in direct contrast to those in solution, where the N1 and N3 are close enough in acidity to be unresolvable. Such a separation of acidities in the gas phase may be why N1 is the preferred site of glycosylation, and why UDGase cleavage of uracil from DNA is not unfavorable, since the uracil $\mathrm{N1}^{-}$is relatively stable in a nonpolar environment. Calculations conducted at B3LYP $/ 6-31+G^{*}$ are in agreement with the experimental values. The bracketing of several of these sites involved utilization of a novel protocol to measure the less acidic site in a molecule that has more than one acidic site, establishing the generality of this method. In molecules with more than two acidic sites, only the two most acidic sites were bracketable, which is attributable to a kinetic effect.

\section{Acknowledgments}

The authors thank the National Science Foundation (CHE0092215), ACS-PRF (grant no. 32732-G4), the Rutgers Environmental Health Sciences Exploratory Research Grant Program, and the Rutgers Busch Grant Program for support, and the National Center for Supercomputing Applications, the High Performance Computing Center at the University of Kentucky, and the Boston University Scientific Computing Facilities for computational resources. They are also grateful to Professor Scott Gronert for valuable discussions.

\section{References}

1. Nguyen, M. T.; Chandra, A. K.; Zeegers-Huyskens, T. Protonation and Deprotonation Energies of Uracil. J. Chem. Soc., Faraday Trans. 1998, 94, 1277-1280.

2. Chandra, A. K.; Nguyen, M. T.; Uchimaru, T.; ZeegersHuyskens, T. Protonation and Deprotonation Enthalpies of Guanine and Adenine and Implications for the Structure and
Energy of Their Complexes with Water: Comparison with Uracil, Thymine, and Cytosine. J. Phys. Chem. A 1999, 103, 8853-8860.

3. Saenger, W. Principles of Nucleic Acid Structure. SpringerVerlag: New York, 1984.

4. Dianov, G.; Sedgwick, B.; Daly, G.; Olsson, M.; Lovett, S.; Lindahl, T. Release of 5'-Terminal Deoxyribose-Phosphate Residues from Incised Abasic Sites in DNA by the Escherichia coli RecJ Protein. Nucleic Acids Res. 1994, 22, 993-998.

5. Savva, R.; McAuley-Hecht, K.; Brown, T.; Pearl, L. The Structural Basis of Specific Base-Excision Repair by Uracil-DNA Glycosylase. Nature 1995, 373, 487-493.

6. Radzicka, A.; Wolfenden, R. A Proficient Enzyme. Science 1995, 267, 90-93.

7. Lee, J. K.; Houk, K. N. A Proficient Enzyme Revisited: The Predicted Mechanism for Orotidine Monophosphate Decarboxylase. Science 1997, 276, 942-945.

8. Lundegaard, C.; Jensen, K. F. Kinetic Mechanism of Uracil Phosphoribosyltransferase from Escherichia coli and Catalytic Importance of the Conserved Proline in the PRPP Binding Site. Biochem. 1999, 38, 3327-3334, and references therein.

9. Jordan, F.; Li, H.; Brown, A. Remarkable Stabilization of Zwitterionic Intermediates May Account for a Billion-fold Rate Acceleration by Thiamin Diphosphate-Dependent Decarboxylases. Biochem. 1999, 38, 6369-6373.

10. Simonson, T.; Brooks, C. L., III. Charge Screening and the Dielectric Constant of Proteins: Insights from Molecular Dynamics. J. Am. Chem. Soc. 1996, 118, 8452-8458.

11. Gilson, M. K.; Honig, B. H. The Dielectric Constant of a Folded Protein. Biopolymers 1986, 25, 2097-2119.

12. Lowry, T. H.; Richardson, K. S. Mechanism and Theory in Organic Chemistry; 3rd ed. Harper and Row, Publishers: New York, 1987.

13. McEwen, W. K. A Further Study of Extremely Weak Acids. J. Am. Chem. Soc. 1936, 58, 1124-1129.

14. Kurinovich, M. A.; Lee, J. K. The Acidity of Uracil from the Gas Phase to Solution: The Coalescence of the N1 and N3 Sites and Implications for Biological Glycosylation. J. Am. Chem. Soc. 2000, 122, 6258-6262.

15. Greco, F.; Liguori, A.; Sindona, G.; Uccella, N. Gas-Phase Proton Affinity of Deoxyribonucleosides and Related Nucleobases by Fast Atom Bombardment Tandem Mass Spectrometry. J. Am. Chem. Soc. 1990, 112, 9092-9096.

16. Green-Church, K. B.; Limbach, P. A. Mononucleotide GasPhase Proton Affinities as Determined by the Kinetic Method. J. Am. Soc. Mass Spectrom. 2000, 11, 24-32.

17. Wilson, M. S.; McCloskey, J. A. Chemical Ionization Mass Spectrometry of Nucleosides. Mechanisms of Ion Formation and Estimations of Proton Affinity. J. Am. Chem. Soc. 1975, 97, 3436-3444.

18. Meot-Ner (Mautner), M. Ion Thermochemistry of Low-Volatility Compounds in the Gas Phase. 2. Intrinsic Basicities and Hydrogen-Bonded Dimers of Nitrogen Heterocyclics and Nucleic Bases. J. Am. Chem. Soc. 1979, 101, 2396-2403.

19. Shroyer, M. J. N.; Bennett, S. E.; Putnam, C. D.; Tainer, J. A.; Mosbaugh, D. W. Mutation of an Active Site Residue in Escherichia coli Uracil-DNA Glycosylase: Effect on DNA Binding, Uracil Inhibition and Catalysis. Biochem. 1999, 38, 48344845.

20. Drohat, A. C.; Xiao, G.; Tordova, M.; Jagadeesh, J.; Pankiewicz, K. W.; Watanabe, K. A.; Gilliland, G. L.; Stivers, J. T. Heteronuclear NMR and Crystallographic Studies of Wild-Type and H187Q Escherichia coli Uracil DNA Glycosylase: Electrophilic Catalysis of Uracil Expulsion by a Neutral Histidine 187. Biochem. 1999, 38, 11876-11886.

21. Drohat, A. C.; Jagadeesh, J.; Ferguson, E.; Stivers, J. T. Role of Electrophilic and General Base Catalysis in the Mechanism of 
Escherichia coli Uracil DNA Glycosylase. Biochem. 1999, 38, 11866-11875.

22. Drohat, A. C.; Stivers, J. T. NMR Evidence for an Unusually Low N1 pKa for Uracil Bound to Uracil DNA Glycosylase: Implications for Catalysis. J. Am. Chem. Soc. 2000, 122, 18401841.

23. Luo, N.; Mehler, E.; Osman, R. Specificity and Catalysis of Uracil DNA Glycosylase. A Molecular Dynamics Study of Reactant and Product Complexes with DNA. Biochem. 1999, 38, 9209-9220.

24. McClard, R. W.; Black, M. J.; Livingstone, L. R.; Jones, M. E. Isolation and Initial Characterization of the Single Polypeptide that Synthesizes Uridine-5'-Monophosphate from Orotate in Ehrlich ascites carcinoma. Purification by Tandem Affinity Chromatography of Uridine-5'-Monophosphate Synthase. Biochem. 1980, 19, 4699-4706.

25. Bruice, T. C.; Benkovic, S. Bioorganic Mechanisms, Vol. II. W. A. Benjamin: New York, 1966.

26. Bender, M. L. Mechanisms of Homogeneous Catalysis from Protons to Proteins. Wiley-Interscience: New York, 1971.

27. Snider, M. J.; Wolfenden, R. The Rate of Spontaneous Decarboxylation of Amino Acids. J. Am. Chem. Soc. 2000, 122, 11507-11508.

28. Parikh, S. S.; Walcher, G.; Jones, G. D.; Slupphaug, G.; Krokan, H. E.; Blackburn, G. M.; Tainer, J. A. Uracil-DNA GlycosylaseDNA Substrate and Product Structures: Conformational Strain Promotes Catalytic Efficiency by Coupled Stereoelectronic Effects. Proc. Natl. Acad. Sci. U.S.A. 2000, 97, 5083-5088.

29. Xiao, G.; Tordova, M.; Jagadeesh, J.; Drohat, A.; Stivers, J. T.; Gilliland, G. L. Crystal Structure of Escherichia coli Uracil DNA Glycosylase and Its Complexes with Uracil and Glycerol: Structure and Glycosylase Mechanism Revisited. Proteins Struct. Funct. Genet. 1999, 35, 13-24.

30. Stivers, J. T.; Pankiewicz, K. W.; Watanabe, K. A. Kinetic Mechanism of Damage Site Recognition and Uracil Flipping by Escherichia coli Uracil DNA Glycosylase. Biochem. 1999, 38, 952-963.

31. Drohat, A. C.; Stivers, J. T. Escherichia coli Uracil DNA Glycosylase: NMR Characterization of the Short Hydrogen Bond from His187 to Uracil O2. Biochem. 2000, 39, 11865-11875.

32. Dong, J.; Drohat, A. C.; Stivers, J. T.; Pankiewicz, K. W.; Carey, P. R. Raman Spectroscopy of Uracil DNA Glycosylase-DNA Complexes: Insights into DNA Damage Recognition and Catalysis. Biochem. 2000, 39, 13241-13250.

33. Werner, R. M.; Stivers, J. T. Kinetic Isotope Effect Studies of the Reaction Catalyzed by Uracil DNA Glycosylase: Evidence for an Oxocarbenium Ion-Uracil Anion Intermediate. Biochem. 2000, 39, 14054-14064.

34. Jiang, Y. L.; Stivers, J. T. Reconstructing the Substrate for Uracil DNA Glycosylase: Tracking the Transmission of Binding Energy in Catalysis. Biochem. 2001, 40, 7710-7719.

35. Dinner, A. R.; Blackburn, G. M.; Karplus, M. Uracil-DNA Glycosylase Acts by Substrate Autocatalysis. Nature 2001, 413, 752-755.

36. Beak, P.; Siegel, B. Mechanism of Decarboxylation of 1,3Dimethylorotic Acid. A Model for Orotidine 5'-Phosphate Decarboxylase. J. Am. Chem. Soc. 1976, 98, 3601-3606.

37. Acheson, S. A.; Bell, J. B.; Jones, M. E.; Wolfenden, R. Orotidine-5'-Monophosphate Decarboxylase Catalysis: Kinetic Isotope Effects and the State of Hybridization of a Bound Transition-State Analogue. Biochem. 1990, 29, 3198-3202.

38. Levine, H. L.; Brody, R. S.; Westheimer, F. H. Inhibition of Orotidine-5'-Phosphate Decarboxylase by $1-\left(5^{\prime}-\mathrm{Phospho-} \beta\right.$-DRibofuranosyl)barbituric Acid, 6-Azauridine 5'-Phosphate, and Uridine 5'-Phosphate. Biochem. 1980, 19, 4993-4999.

39. Smiley, J. A.; Paneth, P.; O'Leary, M. H.; Bell, J. B.; Jones, M. E. Investigation of the Enzymatic Mechanism of Yeast Orotidine-
5'-Monophosphate Decarboxylase Using ${ }^{13} \mathrm{C}$ Kinetic Isotope Effects. Biochem. 1991, 30, 6216-6223.

40. Smiley, J. A.; Jones, M. E. A Unique Catalytic and InhibitorBinding Role for Lys93 of Yeast Orotidylate Decarboxylase. Biochem. 1992, 31, 12162-12168.

41. Smiley, J. A.; Benkovic, S. J. Selection of Catalytic Antibodies for a Biosynthetic Reaction from a Combinatorial cDNA Library by Complementation of an Auxotrophic Escherichia coli: Antibodies for Orotate Decarboxylation. Proc. Natl. Acad. Sci. U.S.A. 1994, 91, 8319-8323.

42. Smiley, J. A.; Benkovic, S. J. Expression of an Orotate Decarboxylating Catalytic Antibody Confers 5-Fluoroorotate Sensitivity to a Pyrimidine Auxotrophic Escherichia coli: An Example of Intracellular Prodrug Activation. J. Am. Chem. Soc. 1995, $117,3877-3878$.

43. Smiley, J. A.; Hay, K. M.; Levison, B. S. A Reexamination of the Substrate Utilization of 2-Thioorotidine-5'-Monophosphate by Yeast Orotidine-5'-Monophosphate Decarboxylase. Bioorg. Chem. 2001, 29, 96-106.

44. Silverman, R. B.; Groziak, M. P. Model Chemistry for a Covalent Mechanism of Action of Orotidine 5'-Phosphate Decarboxylase. J. Am. Chem. Soc. 1982, 104, 6434-6439.

45. Cui, W.; DeWitt, J. G.; Miller, S. M.; Wu, W. No Metal Cofactor in Orotidine 5'-Monophosphate Decarboxylase. Biochem. Biophys. Res. Comm. 1999, 259, 133-135.

46. Ehrlich, J. I.; Hwang, C.-C.; Cook, P. F.; Blanchard, J. S. Evidence for a Stepwise Mechanism of OMP Decarboxylase. J. Am. Chem. Soc. 1999, 121, 6966-6967.

47. Nakanishi, M. P.; Wu, W. Mechanism of Decarboxylation of 1,3-Dimethylorotic Acid Revisited: Trapping of the Reaction Intermediate. Tetrahedron Lett. 1998, 39, 6271-6272.

48. Wu, W.; Ley-han, A.; Wong, F. M.; Austin, T. J.; Miller, S. M. Decarboxylation of 1,3-Dimethylorotic Acid Revisited: Determining the Role of N-1. Bioorg. Med. Chem. Lett. 1997, 7, 2623-2628.

49. Singleton, D. A.; Merrigan, S. A.; Kim, B. J.; Beak, P.; Phillips, L. M.; Lee, J. K. ${ }^{13} \mathrm{C}$ Kinetic Isotope Effects and the Mechanism of the Uncatalyzed Decarboxylation of Orotic Acid. J. Am. Chem. Soc. 2000, 122, 3296-3300.

50. Appleby, T. C.; Kinsland, C.; Begley, T. P.; Ealick, S. E. The Crystal Structure and Mechanism of Orotidine 5'-Monophosphate Decarboxylase. Proc. Natl. Acad. Sci. U.S.A. 2000, 97, 2005-2010.

51. Harris, P.; Poulsen, J.-C. N.; Jensen, K. F.; Larsen, S. Structural Basis for the Catalytic Mechanism of a Proficient Enzyme: Orotidine 5'-Monophosphate Decarboxylase. Biochem. 2000, 39, 4217-4224.

52. Miller, B. G.; Snider, M. J.; Short, S. A.; Wolfenden, R. Contribution of Enzyme-Phosphoribosyl Contacts to Catalysis by Orotidine 5'-Phosphate Decarboxylase. Biochem. 2000, 39, 8113-8118.

53. Miller, B. G.; Hassell, A. M.; Wolfenden, R.; Milburn, M. V.; Short, S. A. Anatomy of a Proficient Enzyme: The Structure of Orotidine 5'-Monophosphate Decarboxylase in the Presence and Absence of a Potential Transition State Analog. Proc. Natl. Acad. Sci. U.S.A. 2000, 97, 2011-2016.

54. Wu, N.; Mo, Y.; Gao, J.; Pai, E. F. Electrostatic Stress in Catalysis: Structure and Mechanism of the Enzyme Orotidine Monophosphate Decarboxylase. Proc. Natl. Acad. Sci. U.S.A. 2000, 97, 2017-2022.

55. Warshel, A.; Strajbl, M.; Villa, J.; Florian, J. Remarkable Rate Enhancement of Orotidine 5'-Monophosphate Decarboxylase is Due to Transition-State Stabilization Rather than to GroundState Destabilization. Biochem. 2000, 39, 14728-14738.

56. Warshel, A.; Florian, J.; Strajbl, M.; Villa, J. Circe Effect versus Enzyme Preorganization: What Can Be Learned from the 
Structure of the Most Proficient Enzyme? Chem. Bio. Chem. 2001, 2, 109-111.

57. Begley, T. P.; Appleby, T. C.; Ealick, S. E. The Structural Basis for the Remarkable Catalytic Proficiency of Orotidine 5'Monophosphate Decarboxylase. Curr. Opin. Struct. Biol. 2000, 10, 711-718.

58. Houk, K. N.; Lee, J. K.; Tantillo, D. J.; Bahmanyar, S.; Hietbrink, B. N. Crystal Structures of Orotidine 5'-Monophosphate Decarboxylase: Does the Structure Reveal the Mechanism of the Most Proficient Enzyme? Chem. Bio. Chem. 2001, 2, 113-118.

59. Rishavy, M. A.; Cleland, W. W. Determination of the Mechanism of Orotidine 5'-Monophosphate Decarboxylase by Isotope Effects. Biochem. 2000, 39, 4569-4574.

60. Phillips, L. M.; Lee, J. K. Theoretical Studies of Mechanisms and Kinetic Isotope Effects on the Decarboxylation of Orotic Acid and Derivatives. J. Am. Chem. Soc. 2001, 123, 12067-12073.

61. Nakanishi, K.; Suzuki, N.; Yamazaki, F. Ultraviolet Spectra of N-Heterocyclic Systems. I. The Anions of Uracils. Bull. Chem. Soc. Jpn. 1961, 34, 53-57.

62. Kimura, E.; Kitamura, H.; Koike, T.; Shiro, M. Facile and Selective Electrostatic Stabilization of Uracil N(1)-Anion by a Proximate Protonated Amine: A Chemical Implication for Why Uracil N(1) is Chosen for Glycosylation Site. J. Am. Chem. Soc. 1997, 119, 10909-10919.

63. Amster, I. J. Fourier Transform Mass Spectrometry. J. Mass. Spec. 1996, 31, 1325-1337, and references therein.

64. Marshall, A. G.; Grosshans, P. B. Fourier Transform Ion Cyclotron Resonance Mass Spectrometry: The Teenage Years. Anal. Chem. 1991, 63, 215A-229A, and references therein.

65. O'Hair, R. A. J.; Gronert, S.; DePuy, C. H.; Bowie, J. H. Gas-Phase Ion Chemistry of the Acetic Acid Enolate Anion $\left[\mathrm{CH}_{2} \mathrm{CO}_{2} \mathrm{H}\right]^{-}$. J. Am. Chem. Soc. 1989, 111, 3105-3106.

66. Grabowski, J. J.; Cheng, X. Gas-Phase Formation of the Enolate Monoanion of Acetic Acid by Proton Abstraction. J. Am. Chem. Soc. 1989, 111, 3106-3108.

67. Wenthold, P. G.; Squires, R. R. Biradical Thermochemistry from Collision-Induced Dissociation Threshold Energy Measurements. Absolute Heats of Formation of ortho-, meta-, and para-Benzyne. J. Am. Chem. Soc. 1994, 116, 6401-6412.

68. Wenthold, P. G.; Paulino, J. A.; Squires, R. R. The Absolute Heats of Formation of $o_{-}^{-,} m_{-}$, and $p$-Benzyne. J. Am. Chem. Soc. 1991, 113, 7414-7415.

69. Wenthold, P. G.; Squires, R. R. Determination of the Gas Phase Acidities of Halogen-Substituted Aromatic Compounds Using the Silane-Cleavage Method. J. Mass. Spec. 1995, 30, 17-24.

70. Hare, M. C.; Marimanikkuppam, S. S.; Kass, S. R. Acetamide Enolate: Formation, Reactivity, and Proton Affinity. Int. J. Mass Spectrom. 2001, 210/211, 153-163.

71. Kass, S. R.; Guo, H.; Dahlke, G. D. The Formation and Reactivity of the Thiomethyl Anion. J. Am. Soc. Mass Spectrom. 1990, 1, 366-371.

72. Anderson, K. K.; Kass, S. R. Vinyl Anion Synthesis in the Gas Phase. Tetrahedron Lett. 1989, 30, 3045-3048.

73. Chou, P. K.; Kass, S. R. (E) and (Z) Vinyl Anions. The Formation and Characterization of Regio- and Stereoisomers in the Gas Phase. J. Am. Chem. Soc. 1991, 113, 4357-4359.

74. Sachs, R. K.; Kass, S. R. 3-Carbomethoxycyclopropen-3-yl Anion. Formation and Characterization of an Antiaromatic Ion. J. Am. Chem. Soc. 1994, 116, 783-784.

75. Baschky, M. C.; Peterson, K. C.; Kass, S. R. Stereospecificity in the Gas Phase. Formation and Characterization of Configurationally Stable Cyclopropyl Anions. J. Am. Chem. Soc. 1994, 116, 7218-7224.

76. Merrill, G. N.; Dahlke, G. D.; Kass, S. R. $\beta$-Cyanoethyl Anion: Lusus naturae. J. Am. Chem. Soc. 1996, 118, 4462-4468.
77. Reed, D. R.; Kass, S. R. An Experimental Determination of the $\alpha$ and $\beta \mathrm{C}-\mathrm{H}$ Bond Dissociation Energies in Naphthalene. J. Mass. Spec. 2000, 35, 534-539.

78. Ingemann, S.; Nibbering, N. M. M. On the Dipole Stabilized Carbanions Derived from Methyl Formate and $N, N$-Dimethylformamide. J. Org. Chem. 1985, 50, 682-689.

79. Frisch, M. J.; Trucks, G. W.; Schlegel, H. B.; Gill, P. M. W.; Johnson, B. G.; Robb, M. A.; Cheeseman, J. R.; Keith, T.; Petersson, G. A.; Montgomery, J. A.; Raghavachari, K.; AlLaham, M. A.; Zakrzewski, V. G.; Ortiz, J. V.; Foresman, J. B.; Peng, C. Y.; Ayala, P. Y.; Chen, W.; Wong, M. W.; Andres, J. L.; Replogle, E. S.; Gomperts, R.; Martin, R. L.; Fox, D. J.; Binkley, J. S.; Defrees, D. J.; Baker, J.; Stewart, J. P.; Head-Gordon, M.; Gonzalez, C.; Pople, J. A. GAUSSIAN94, Rev. E.2. Gaussian, Inc.: Pittsburgh, 1995.

80. Frisch, M. J.; Trucks, G. W.; Schlegel, H. B.; Scuseria, G. E.; Robb, M. A.; Cheeseman, J. R.; Zakrzewski, V. G.; Montgomery, J. A. Jr.; Stratmann, R. E.; Burant, J. C.; Dapprich, S.; Millam, J. M.; Daniels, A. D.; Kudin, K. N.; Strain, M. C.; Farkas, O.; Tomasi, J.; Barone, V.; Cossi, M.; Cammi, R.; Mennucci, B.; Pomelli, C.; Adamo, C.; Clifford, S.; Ochterski, J.; Petersson, G. A.; Ayala, P. Y.; Cui, Q.; Morokuma, K.; Malick, D. K.; Rabuck, A. D.; Raghavachari, K.; Foresman, J. B.; Cioslowski, J.; Ortiz, J. V.; Baboul, A. G.; Stefanov, B. B.; Liu, G.; Liashenko, A.; Piskorz, P.; Komaromi, I.; Gomperts, R.; Martin, R. L.; Fox, D. J.; Keith, T.; Al-Laham, M. A.; Peng, C. Y.; Nanayakkara, A.; Gonzalez, C.; Challacombe, M.; Gill, P. M. W.; Johnson, B.; Chen, W.; Wong, M. W.; Andres, J. L.; Head-Gordon, M.; Replogle, E. S.; Pople, J. A. GAUSSIAN98. Gaussian, Inc.: Pittsburgh, 1998.

81. Gronert, S.; Feng, W. Y.; Chew, F.; Wu, W. The Gas Phase Acid/Base Properties of 1,3-Dimethyluracil, 1-Methyl-2-pyridone, and 1-Methyl-4-pyridone: Relevance to the Mechanism of Orotidine 5'-Monophosphate Decarboxylase. Int. J. Mass Spectrom. 2000, 196, 251-258.

82. Li, W.; Santos, I.; Marshall, A. G. Determination of the Gas-Phase Acidities of Uracil and 5-Fluorouracil by FT-ICR Mass Spectrometry. 1996 ASMS Abstracts Portland, Oregon, May, 1996.

83. Chandra, A. K.; Nguyen, M. T.; Zeegers-Huyskens, T. Theoretical Study of the Interaction Between Thymine and Water. Protonation and Deprotonation Enthalpies and Comparison with Uracil. J. Phys. Chem. A 1998, 102, 6010-6016.

84. Graindourze, M.; Smets, J.; Zeegers-Huyskens, T.; Maes, G. FT-IR Spectroscopic Study of Uracil Derivatives and their Hydrogen-Bonded Complexes with Model Proton Donors. Part 6. Proton Transfer in Uracil. $\mathrm{HCl}$ Complexes Isolated in Concentrated or Strongly Annealed Argon Matrices. J. Mol. Struct. (THEOCHEM) 1994, 318, 55-64.

85. Smets, J.; Graindourze, M.; Zeegers-Huyskens, T.; Maes, G. FT-IR Spectroscopic Study of Uracil Derivatives and their Hydrogen-Bonded Complexes with Model Proton Donors. Part 5. Complexes of Uracils with Hydrogen Chloride in Argon Matrices. J. Mol. Struct. (THEOCHEM) 1994, 318, 37-53.

86. Lias, S. G.; Bartmess, J. E.; Liebman, J. F.; Holmes, J. L.; Levin, R. D.; Mallard, W. G.NIST Thermochemical Tables. J. Phys. Chem. Ref. Data 1988, 17, Suppl. 1.

87. NIST Chemistry WebBook, NIST Standard Reference Database Number 69, November 1998; Mallard, W. G.; Linstrom, P. J., Eds.; National Institute of Standards and Technology: Gaithersburg 1998; http://webbook.nist.gov.

88. Kato, S.; DePuy, C. H.; Gronert, S.; Bierbaum, V. M. Gas Phase Hydrogen/Deuterium Exchange Reactions of Fluorophenyl Anions. J. Am. Soc. Mass Spectrom. 2000, 10, 840-847. 